\title{
Study of antibacterial activity of selected Iranian plant extracts on Helicobacter pylori
}

\author{
Abachi S. ${ }^{1 *}$, Khademi F. ${ }^{2}$, Fatemi H. ${ }^{2}$, Malekzadeh F. ${ }^{1}$ \\ ${ }^{1}$ Department of Food Science, Agriculture \& Natural Resources Research Center, Qom, Iran \\ ${ }^{2}$ Department of Microbiology, Agriculture Research Center, Tabriz, Iran
}

\begin{abstract}
Helicobacter pylori is a major contributor to chronic gastritis, peptic, duodenal ulcers, and is associated with distal adenocarcinoma. Increasing resistance of $H$. pylori to common antibiotics is becoming an issue and finding new treatments are crucial. Aqueous and ethanolic extracts of Glycyrrhiza glabra, Filipendula ulmaria, Argentina anserine, Crataegus douglasii, Rubus fruticosus were tested, by agar diffusion and agar dilution method, against H. pylori clinical isolates. Among the aqueous extracts studied, G. glabra extract had the highest antibacterial effect on $\mathrm{H}$. pylori (mean diameter of inhibition zone $14.7 \mathrm{~mm}$ ) followed by Filipendula ulmaria, Rubus fruticosus, Argentina anserine, and Crataegus douglasii. Among the ethanolic extracts, Glycyrrhiza glabra extract was the most effective one (mean diameter of inhibition zone $9.9 \mathrm{~mm}$ ), followed by Filipendula ulmaria, Argentina anserine, Rubus fruticosus, and Crataegus douglasii. Given the high levels of antibacterial activities of aqueous and ethanolic extracts of Glycyrrhiza glabra and Filipendula ulmaria, the next step is to identify the antimicrobial constituents of these plants.
\end{abstract}

Keywords: Helicobacter pylori, Glycyrrhiza glabra, Filipendula ulmaria

\section{Introduction}

Italian researcher, Bizzozero, in 1983, found helical microbes in stomach and in the following years, 1987; Goodwin and Marshall discovered a bacterium which was named Campylobacter. Lastly in 1998, a new genus called Helicobacter was proposed by Goodwin and his colleagues. The discovery of this microorganism opened a new era in the pathology of digestive system [1-3]. Helicobacter pylori, found in biopsic samples of digestive system, has drawn more attention because there are evidences of this bacterium's pathogenic activities. H. pylori is found in stomach mucus, sometimes in duodenal mucus, can form colonies in Barrett's esophagus and is known as a probable cause of esophagitis [3,4]. More importantly, there are evidences of gastric adenocarcinoma development caused by $H$. pylori infections[5,6].

H. pylori is an active, gram-negative, microaerophilic, spirally shaped bacterium with lophotrichous flagellation. It grows in the form of curved rods in agar medium and coccoid form in old desiccated cultures. $H$. pylori is oxidas, urease, catalase, and alkaline phosphatase positive.

H. pylori eradication therapy is carried out through therapeutic treatments as single or multidrug regimens[7,8].The antibiotics amoxicillin, clarithromycin, and metronidazole inhibit gastric acid secretion. In addition, $\mathrm{H}_{2}$ blockers and bismuth salts are used in $H$. pylori treatment. Unsuccessful treatments in full removal of infections, recurrent infections, and increasing resistance of $H$. pylori to therapeutic treatments $(5-20 \%$ of treatments have been reported to fail due to $H$. pylori resistance to treatments) all have led to continuous research on finding new ways of treatments $[9,10]$.

Many studies now focus on anti $H$. pylori effects of medicinal plants, which are of limited side effects on tissues. For centuries, medicinal plants have been used in traditional medicine to treat a wide range of diseases including digestive disorders such as ulcers. Aqueous extract of thyme and ethanolic extract of cinnamon have anti $H$. pylori effects [11-13].

It has been suggested that thyme is more effective than cinnamon since it inhibits the urease activity of H. pylori[14]. In addition, wild thyme is among the herbs which have been studied for anti $H$. pylori effects, particularly because of its easily produced aqueous extract, and its effects have been reported to be potentially more significant than those of cinnamon[15,16].

Antimicrobial activities of cinnamon and turmeric, which are used globally as food additive, are particularly known in the eastern hemisphere. Antibacterial effects of turmeric oil on several bacteria, including Escherichia coli, have been studied widely [17,18]. Ginger's inhibiting effects on Micrococcus luteus have also been examined $[19,20]$. Since some food additives have antibacterial effects on $H$. pylori, they can be used in $H$. pylori infection treatment, and in control of its transmission[21]. Therefore, studies should be conducted to examine antibacterial activities of herbal extracts and identifying their potent constituents. 


\begin{abstract}
II. Materials and methods
2.1 Strains and growth conditions

Gastric biopsic samples taken from patients, provided by the endoscopy department of Shafa medical care center, diagnosed with peptic ulcer, duodenal ulcer, gastritis and stomach cancer were used in this study. The samples were transported to the laboratory in transport kits and, were finely chopped in tissue grinder; $1 \mathrm{ml}$ of sterile saline solution was added and, then were vortexed at high speed. Microscopic examination of smears was conducted, as a standard bacteriology test, to preselect the positive specimens. Phase-contrast microscopy can be utilized for examination of biopsies allowing us for a quick diagnosis of typical spirals morphology of Helicobacter.

In the next step, serial dilutions of the positive homogenates were prepared (up to $10^{-5}$ of original concentration). $100 \mu \mathrm{l}$ of the last two dilutions were cultured, direct plating, on serum added brain heart agar medium for primary isolation of bacteria. For selective isolation campylobacter blood agar containing 5\% defibrinated sheep blood, vancomycin $(10 \mathrm{mg} / \mathrm{l})$, polymyxin B $(0.25 \mathrm{mg} / \mathrm{l})$, trimethoprim $(5 \mathrm{mg} / \mathrm{l})$, and amphotericin B $(2 \mathrm{mg} / \mathrm{l})$ were used. The plates were incubated in $100 \%$ humidity at $37^{\circ} \mathrm{C}$ for $5-7$ days in microaerophilic Jar $\left(\mathrm{CO}_{2} 10 \%, \mathrm{O}_{2} 5 \%\right)$. The agar plates were checked for growth from day 3 through day 7 . An isolate was identified as $\mathrm{H}$. pylori on the basis of positive catalase, oxidase, and urease reactions, typical colony morphology (small, round colonies), and the presence of characteristic curved gram-negative bacilli on Gramstained smears. Suspect colonies were skipped routinely [7,22-24].
\end{abstract}

\title{
2.2 Plant extract preparation
}

G. glabra root , F. ulmaria flower ,A. anserine root ,C. douglasii berry, and R. fruticosus leaf, plant parts, were washed under running tap-water, dried in shade, powdered by electric grinder and then extracts were prepared ,aqueous and ethanolic. Ten grams of each plant powder was put in water and ten grams in ethanol (maceration with an herb-to-solvent ratio of 1:10) then the solutions were incubated for 72 hours at $32{ }^{\circ} \mathrm{C}$ to improve and speed up the maceration process. Supernatant was filtered (Whatman no. 1 filter paper disc), and concentrated using vacuum distillation. The concentrated extracts were then placed on watch glass and heated, $40{ }^{\circ} \mathrm{C}$, to speed the evaporation of solvents. Finally, dried extracts of the plants were obtained [25-28].

\subsection{Evaluation of $H$. pylori sensitivity to aqueous and ethanolic extracts of G. glabra, F. ulmaria, $A$. anserine , $C$. douglasii,$R$. fruticosus using agar dilution}

Ten $H$. pylori clinical isolates (ulcer samples; 4, gastritis samples; 4, and stomach cancer samples; 2) were used to investigate the antibacterial effects of these plants. Aqueous extracts of G. glabra, F. ulmaria, A. anserine, C. douglasii, R. fruticosus were added to Brucella Blood Agar (BRU) with 5\% blood (at concentration series of $50,100,150,200,250,300,350,400,450$, and $500 \mu \mathrm{g} / \mathrm{ml}$ ). Suspensions of bacteria were prepared with $3 \times 10^{7}$ bacteria per ml.

$5 \mu \mathrm{l}$ of each suspension was dripped onto the BRU containing the extracts, and the plates were then placed into the anaerobic jar. After addition of distilled water to the gas-pack, we then tightened the jar lid and incubated the jar at $37{ }^{\circ} \mathrm{C}$ in an incubator with $5 \% \mathrm{CO}_{2}$. After five days, minimum inhibitory concentrations (MIC) of the extracts were measured [29].

\subsection{Evaluation of $\boldsymbol{H}$. pylori sensitivity to ethanolic extracts of G. glabra, F. ulmaria, A. anserine, $C$. douglasii, $R$. fruticosus using agar diffusion}

Isolated bacteria grown on plates, containing campylobacter blood agar with 5\% defibrinated sheep blood, were used to prepare the bacterial suspension, $3 \times 10^{7}$ bacteria per $\mathrm{ml}$. Then, $50 \mu \mathrm{l}$ of the suspension was added to Müller-Hinton agar with $5 \%$ blood. Sterile blank discs were put on the plates and $10 \mu \mathrm{l}$ of ethanolic extracts of G. glabra, F. ulmaria, A. anserine, C. douglasii, R. fruticosus was dropped to the blank discs at 400 $\mu \mathrm{g} / \mathrm{ml}$ concentration. After two days of incubation, the plates were examined for inhibition zone [30-32].

\section{Results}

In a parallel study, 108 gastric mucosal biopsy specimens were obtained from 36 consecutive dyspeptic patients (25 males and 11 females) undergoing endoscopy. Utilizing phase-contrast microscopic examination of smears and the selective cultivation, H. pylori was detected in 10 patients (6 males and 4 females). All samples were oxidase, catalase, and urease-positive. In addition, they were sensitive to cephalothin and resistant to nalidixic acid.

Minimum inhibitory concentrations were of $150-300 \mu \mathrm{g} / \mathrm{ml}$ for G. glabra ,250-350 $\mu \mathrm{g} / \mathrm{ml} \mathrm{for} F$. ulmaria , $300-400 \mu \mathrm{g} / \mathrm{ml}$ for A. anserine, $350-450 \mu \mathrm{g} / \mathrm{ml}$ for C. douglasii , $400-450 \mu \mathrm{g} / \mathrm{ml}$ for $R$. fruticosus for different clinical isolates of $H$. pylori (Table III).

Aqueous extracts of G. glabra (inhibition zone 12-17 mm) was of stronger antibacterial effects compared to its ethanolic extracts. Among aqueous and ethanolic extracts investigated, the greatest effect was recorded for 
G. glabra, notably significant, followed by aqueous extracts of F. ulmaria, A. anserine, $R$. fruticosus, and $C$. douglasii (Tables I and II).

The results suggest greater inhibition effects of aqueous extracts for F. ulmaria, A. anserine, $C$. douglasii, and $R$. fruticosus compared to their ethanolic extracts. The difference however was not statistically significant.

Table I: Antibacterial effects of aqueous extracts on 10 clinical isolates of $\mathrm{H}$. pylori

\begin{tabular}{|c|c|c|c|c|c|c|c|c|c|c|c|c|}
\hline \multirow{2}{*}{ Medicinal plants } & \multicolumn{8}{|c|}{ Aqueous Extract :Inhibition zone (mm) in fresh clinical isolates of H. pylori } & $\begin{array}{c}\text { Average } \\
\text { result }\end{array}$ \\
\cline { 2 - 16 }$n$ & 1 & 2 & 3 & 4 & 5 & 6 & 7 & 8 & 9 & 10 & Blank & 14.7 \\
\hline Glycyrrhiz glabra & 16 & 12 & 14 & 17 & 16 & 17 & 15 & 14 & 12 & 14 & 0 & 9.3 \\
\hline Filipend ulaulmaria & 11 & 12 & 10 & 6 & 7 & 9 & 10 & 12 & 7 & 9 & 0 & 7.7 \\
\hline Argentina anserina & 12 & 8 & 9 & 6 & 6 & 8 & 6 & 9 & 7 & 6 & 0 & 7.2 \\
\hline $\begin{array}{c}\text { Crataegus } \\
\text { douglasii }\end{array}$ & 8 & 8 & 9 & 6 & 6 & 6 & 6 & 8 & 7 & 8 & 0 & 8 \\
\hline Rubus fruticosus & 9 & 8 & 17 & 6 & 6 & 6 & 6 & 6 & 7 & 9 & 0 & 8 \\
\hline
\end{tabular}

Table II: Antibacterial effects of ethanolic extracts on 10 clinical isolates of $H$. pylori

\begin{tabular}{|c|c|c|c|c|c|c|c|c|c|c|c|c|}
\hline \multirow{2}{*}{ Medicinal Plants } & \multicolumn{9}{|c|}{ Ethanolic Extract : Inhibition zone (mm) in fresh clinical isolates of H. pylori } & \multirow{2}{*}{$\begin{array}{c}\text { Average } \\
\text { result }\end{array}$} \\
\cline { 2 - 15 }$n$ & 1 & 2 & 3 & 4 & 5 & 6 & 7 & 8 & 9 & 10 & Blank & \\
\hline Glycyrrhiz glabra & 12 & 12 & 12 & 6 & 6 & 6 & 12 & 13 & 8 & 12 & 0 & 9.9 \\
\hline Filipendula ulmaria & 9 & 9 & 9 & 6 & 6 & 8 & 12 & 12 & 10 & 8 & 0 & 8.9 \\
\hline Argentina anserina & 8 & 7 & 7 & 6 & 7 & 8 & 10 & 9 & 8 & 6 & 0 & 7.6 \\
\hline Crataegus douglasii & 7 & 7 & 6 & 6 & 6 & 8 & 9 & 7 & 6 & 7 & 0 & 6.9 \\
\hline Rubus fruticosus & 8 & 6 & 8 & 6 & 6 & 8 & 9 & 7 & 9 & 6 & 0 & 7.3 \\
\hline
\end{tabular}

Table III:MIC values of Aqueous and Ethanolic extracts on selected isolates of H. pylori $(\mu \mathrm{g} / \mathrm{ml})$

\begin{tabular}{|c|c|c|c|c|c|c|c|c|c|c|c|}
\hline \multicolumn{8}{|c|}{ MIC values of aqueous and ethanolic extracts on selected isolates of $H$. pylori $(\mu \mathrm{g} / \mathrm{ml})$} \\
\hline \multirow{2}{*}{ H. pylori strains } & 1 & 2 & 3 & 4 & 5 & 6 & 7 & 8 & 9 & 10 \\
\hline \multirow{2}{*}{ Glycyrrhiz glabra } & aqueous & 250 & 200 & 250 & 150 & 200 & 150 & 150 & 200 & 300 & 250 \\
\cline { 2 - 13 } & ethanolic & 300 & 300 & 300 & 200 & 250 & 200 & 250 & 250 & 300 & 300 \\
\hline \multirow{2}{*}{ Filipendula ulmaria } & aqueous & 300 & 300 & 250 & 300 & 250 & 250 & 300 & 250 & 250 & 250 \\
\cline { 2 - 12 } & ethanolic & 350 & 300 & 300 & 300 & 300 & 350 & 300 & 300 & 250 & 300 \\
\hline \multirow{2}{*}{ Argentina anserina } & aqueous & 350 & 350 & 350 & 300 & 350 & 350 & 350 & 300 & 300 & 300 \\
\cline { 2 - 12 } & ethanolic & 400 & 400 & 350 & 400 & 400 & 400 & 350 & 400 & 400 & 350 \\
\hline \multirow{2}{*}{ Crataegus douglasii } & aqueous & 350 & 350 & 350 & 400 & 400 & 350 & 350 & 400 & 400 & 350 \\
\cline { 2 - 11 } & ethanolic & 450 & 400 & 450 & 450 & 450 & 400 & 400 & 450 & 450 & 450 \\
\hline \multirow{2}{*}{ Rubus fruticosus } & aqueous & 400 & 400 & 400 & 450 & 400 & 400 & 400 & 400 & 450 & 400 \\
\cline { 2 - 10 } & ethanolic & 450 & 450 & 450 & 450 & 400 & 450 & 450 & 400 & 450 & 450 \\
\hline
\end{tabular}

\section{Discussion}

H. pylori is a major contributor to chronic gastritis, and peptic and duodenal ulcers, and is also strongly associated with distal adenocarcinoma. Scientists worldwide are extensively searching for new sources of bioactive compounds, especially antimicrobial agents of natural origins considering the prevalence of antibiotic resistancy among the pathogens. .Antimicrobial agents could be of plant origin, medicinal plant derived in the form of essential oil and ethanolic or aqueous extracts. Also antimicrobial antibiotics could be of bacterium source, marine or terrestrial e.g. antifungal and antibacterial metabolites produced by Streptomyces [33].

Given the prevalence of infections in different communities and its increasing resistance to antibiotics, it is extremely important to find alternative treatments and medications for $H$. pylori infections.

In a series of studies, Hill et al. examined anti H. pylori effects of garlic powder and oil [34]. Sato et al. identified the gallic acid in Terminalia chebula and recorded its ethanolic extract's antibacterial effects on methicillin-resistant staphylococci [35].

In a previous study, we found that Allium ascalonicum $\left(\mathrm{MIC}_{50} 128 \mu \mathrm{g} / \mathrm{ml}\right.$ ) has antimicrobial effect on vancomycin resistant Staphylococcus epidermidis another significant pathogenic bacterium, one of major causes of nosocomial infection[36]. 
Another study in China examined the inhibitory effects of allium in patients diagnosed with stomach cancer. The resulted suggested that; increased consumption dose of allium vegetables (e.g. garlic, onion, shallot, etc) would reduce the risk of stomach cancer by $40 \%$ [37]. The results had shown that vegetables of allium family can inhibit the tumor growth, $H$. pylori infections, and vancomycin resistant $S$. epidermidis.

A study by $\mathrm{Li}$ et al. on 30 species of herbs commonly used in Chinese traditional medicine to treat gastric ulcer, anti $H$. pylori activities of the following families were examined against the standard $H$. pylori strain ATCC43504 as well as against $H$. pylori clinical isolates: Apiaceae, Aristolochiaceae, Asteraceae,Elaeagnaceae, Fabaceae, Lauraceae, Lamiaceae,Liliaceae, Magnoliaceae, Meliaceae, Menispermaceae, Myrtaceae, Orchidaceae, Papaveraceae, Piperaceae, Polyporaceae, Primulaceae, Rutaceae, and Zingiberaceae. The findings indicated that a significant number of species examined in the study (both aqueous and ethanolic extracts) have inhibitory effects on $H$. pylori[38].

A study, in Japan, by Funatogawa et al. examined inhibitory effects of hydrolysable tannins extracted from plants on treating infections caused by $H$. pylori. The results showed that these compounds (particularly monomeric tannin) have significant anti $H$. pylori activities due to their impact on lipid bilayer membranes[39]. Ehasnifar examined anti $H$. pylori effects of several plants, including pennyroyal and flowering oregano, and found that pennyroyal had no significant effect of growth inhibition while oregano significantly inhibited $H$. pylori growth[40].

Our findings indicated the highest level of anti $H$. pylori activity in aqueous extract of G. glabra followed by extracts of $F$. ulmaria, $R$. fruticosus, $A$. anserine and $C$. douglasii.

G. glabra (Leguminosae family) is a plant that has long been used in treatment of gastritis. Analysis of G. glabra has revealed that its constituents are of flavonoid, isoflavonoid, chalcone and glycosides groups and those may contribute to its anti $H$. pylori effects. Given the results of this study, it is of great importance to examine the clinical applications of the extract and to develop new food products that can contain G. glabra as a food additive.

\section{Acknowledgements}

The authors would like to thank the Agricultural Research Center of the East Azerbaijan province for their support in carrying out this work.

\section{References}

[1] Solnick JV, O'Rourke J, Lee A, et al. (1993): An uncultured gastric spiral organism is a newly identified Helicobacter in humans. Journal of Infectious Diseases, 168(2), 379-385.

[2] Handa O, Naito Y, Yoshikawa T. (2010): Helicobacter pylori: a ROS-inducing bacterial species in the stomach. Inflammation Research, 59(12), 997-1003

[3] Oshowo A, Gillam D, Botha A, et al. (1998): Helicobacter pylori: the mouth, stomach, and gut axis. Annals of periodontology, $3(1), 276-280$

[4] Shimizu T, Akamatsu T, Sugiyama A, et al. (1996): Helicobacter pylori and the surface mucous gel layer of the human stomach. Helicobacter, 1(4), 207-218.

[5] Parsonnet J, Friedman GD, Vandersteen DP, et al. (1991): Helicobacter pylori infection and the risk of gastric carcinoma. New England Journal of Medicine, 325(16), 1127-1131.

[6] Desforges JF, Peterson WL. (1991): Helicobacter pylori and peptic ulcer disease. New England Journal of Medicine, 324(15), 1043-1048.

[7] Goodwin C, Armstrong J. (1990): Microbiological aspects of Helicobacter pylori (Campylobacter pylori). European Journal of Clinical Microbiology \& Infectious Diseases, 9(1), 1-13

[8] Georgopoulos SD, Papastergiou V, Karatapanis S. (2012): Helicobacter pylori Eradication Therapies in the Era of Increasing Antibiotic Resistance: A Paradigm Shift to Improved Efficacy. Gastroenterol Res Pract, 2012, 757926.

[9] Graham DY, Fischbach L. (2010): Helicobacter pylori treatment in the era of increasing antibiotic resistance. Gut, 59(8), 11431153.

[10] Megraud F, Coenen S, Versporten A, et al. (2013): Helicobacter pylori resistance to antibiotics in Europe and its relationship to antibiotic consumption. Gut, 62(1), 34-42.

[11] Shipradeep, Karmakar S, Sahay Khare R, et al. (2012): Development of probiotic candidate in combination with essential oils from medicinal plant and their effect on enteric pathogens: a review. Gastroenterol Res Pract, 2012, 457150.

[12] Singh D, Kumar TR, Gupt VK, et al. (2012): Antimicrobial activity of some promising plant oils, molecules and formulations. Indian J Exp Biol, 50(10), 714-717.

[13] Castillo SL, Heredia N, Contreras JF, et al. (2011): Extracts of edible and medicinal plants in inhibition of growth, adherence, and cytotoxin production of Campylobacter jejuni and Campylobacter coli. J Food Sci, 76(6), M421-426.

[14] Tabak M, Armon R, Neeman I. (1999): Cinnamon extracts' inhibitory effect on Helicobacter pylori. Journal of Ethnopharmacology, 67(3), 269-277.

[15] Tabak M, Armon R, Potasman I, et al. (1996): In vitro inhibition of Helicobacter pylori by extracts of thyme. J Appl Microbiol, 80(6), 667-672.

[16] Dorman HJ, Deans SG. (2000): Antimicrobial agents from plants: antibacterial activity of plant volatile oils. J Appl Microbiol, 88(2), 308-316.

[17] Negi P, Jayaprakasha G, Rao LJM, et al. (1999): Antibacterial activity of turmeric oil: a byproduct from curcumin manufacture. $J$ Agric Food Chem, 47(10), 4297-4300.

[18] O'Mahony R, Al-Khtheeri H, Weerasekera D, et al. (2005): Bactericidal and anti-adhesive properties of culinary and medicinal plants against Helicobacter pylori. World J Gastroenterol, 11(47), 7499-7507. 
[19] Bartfay WJ, Bartfay E, Johnson JG. (2012): Gram-negative and gram-positive antibacterial properties of the whole plant extract of willow herb (Epilobium angustifolium). Biol Res Nurs, 14(1), 85-89.

[20] Policegoudra RS, Abiraj K, Channe Gowda D, et al. (2007): Isolation and characterization of antioxidant and antibacterial compound from mango ginger (Curcuma amada Roxb.) rhizome. J Chromatogr B Analyt Technol Biomed Life Sci, 852(1-2), 4048.

[21] Liu W, Liu Y, Zhang XZ, et al. (2013): In vitro bactericidal activity of jinghua weikang capsule and its individual herb Chenopodium Ambrosioides L. against antibiotic-resistant H. Pylori. Chin J Integr Med, 19(1), 54-57.

[22] Miendje Deyi VY, Van den Borre C, Fontaine V. (2010): Comparative evaluation of 3 selective media for primary isolation of Helicobacter pylori from gastric biopsies under routine conditions. Diagn Microbiol Infect Dis, 68(4), 474-476.

[23] Chomvarin C, Kulsantiwong P, Chantarasuk Y, et al. (2006): Comparison of media and antibiotic supplements for isolation of Helicobacter pylori from gastric biopsies. Southeast Asian J Trop Med Public Health, 37(6), 1163-1169.

[24] Bazhenkov LG, Khodzhaeva NU, Sadykov RA, et al. (1993): The isolation of Helicobacter pylori from the gastric juice. Klin Lab Diagn(5), 19-22.

[25] Huie CW. (2002): A review of modern sample-preparation techniques for the extraction and analysis of medicinal plants. Anal Bioanal Chem, 373(1), 23-30.

[26] Wang L, Weller CL. (2006): Recent advances in extraction of nutraceuticals from plants. Trends in Food Science \& Technology, 17(6), 300-312.

[27] Khademi F, Abachi S, Mortazavi A, et al. (2013): Screening and isolation of substitute-rennet producing thermophilic phycomycetes, by modified Warcup method and improved selective medium IOSR Journal of Agriculture and Veterinary Science 2(1), 25-31.

[28] Khademi F, Abachi S, Mortazavi A, et al. (2013): Optimization of fungal rennet production by local isolate of Rhizomucor nainitalensis under solid substrate fermentation system. IOSR Journal of Pharmacy and Biological Sciences, 5(2), $115-121$.

[29] Annuk H, Hirmo S, Turi E, et al. (1999): Effect on cell surface hydrophobicity and susceptibility of Helicobacter pylori to medicinal plant extracts. FEMS Microbiol Lett, 172(1), 41-45.

[30] Ahmad N, Zakaria WR, Mohamed R. (2011): Analysis of antibiotic susceptibility patterns of Helicobacter pylori isolates from Malaysia. Helicobacter, 16(1), 47-51.

[31] Ansorg R, von Recklinghausen G, Heintschel von Heinegg E. (1996): Susceptibility of Helicobacter pylori to simethicone and other non-antibiotic drugs. J Antimicrob Chemother, 37(1), 45-52.

[32] Khademi F, Abachi S, Malekzadeh F. (2013): Semi-purification and kinetic study of microfungal rennet synthesized by local isolate of Rhizomucor nainitalensis using solid state fermentation system: concentration methods and determinant factors in clotting activity. European Journal of Experimental Biology, 3(2 ), 30-38.

[33] Khademi F, Abachi S, Malekzadeh F. (2013): Microbial technologies for the Isolation and phylogenetic analysis of Marine and terrestrial bacteria with antifungal or antibacterial activities. Journal of BioScience and Biotechnology, 2(2), 25-36.

[34] O'Gara EA, Hill DJ, Maslin DJ. (2000): Activities of garlic oil, garlic powder, and their diallyl constituents against Helicobacter pylori. Appl Environ Microbiol, 66(5), 2269-2273.

[35] Sato Y, Oketani H, Singyouchi K, et al. (1997): Extraction and purification of effective antimicrobial constituents of Terminalia chebula RETS. against methicillin-resistant Staphylococcus aureus. Biol Pharm Bull, 20(4), 401.

[36] Abachi S, Khademi F, Fatemi H, et al. (2013): Study of Antimicrobial activity of selected Iranian plant extracts on vancomycin resistant Staphylococcus epidermidis. IOSR Journal of Dental and Medical Sciences, 4(1), 59-63.

[37] You W, Zhang L, Gail MH, et al. (1998): Helicobacter pylori infection, garlic intake and precancerous lesions in a Chinese population at low risk of gastric cancer. International journal of epidemiology, 27(6), 941-944.

[38] Li Y, Xu C, Zhang Q, et al. (2005): In vitro anti Helicobacter pylori action of 30 Chinese herbal medicines used to treat ulcer diseases. Journal of Ethnopharmacology, 98(3), 329-333.

[39] Funatogawa K, Hayashi S, Shimomura H, et al. (2004): Antibacterial activity of hydrolyzable tannins derived from medicinal plants against Helicobacter pylori. Microbiology and immunology, 48(4), 251-261.

[40] Malekzadeh F, Ehsanifar H, Shahamat M, et al. (2001): Antibacterial activity of black myrobalan (Terminalia chebula Retz) against Helicobacter pylori. Int J Antimicrob Agents, 18(1), 85-88. 